\title{
Relationship between benthic foraminifera and food resources in South San Francisco Bay, California, USA
}

\author{
Amy E. Lesen* \\ Department of Integrative Biology and Museum of Paleontology, University of California, Berkeley, California 94720-3140, USA \\ Present address: Department of Math and Science, Pratt Institute, 200 Willoughby Avenue, Brooklyn, New York 11205, USA
}

\begin{abstract}
Foraminifera are amongst the most abundant known protists found in marine habitats, and are ecologically important constituents of the benthic meiofauna. The seasonality of San Francisco Bay, USA, makes it an ideal system in which to study the relationships between primary production, organic matter fluxes, and food resources for the benthos. Samples were collected at one site at a depth of $8.8 \mathrm{~m}$ in South San Francisco Bay on monthly cruises for 2 yr from November 1999 through November 2001. Each month, water column parameters (chlorophyll concentration) and sediment parameters (chlorophyll, total organic carbon, nitrogen, amino acids, bacterial abundance) were measured, and benthic foraminiferal population size and biovolume was counted and calculated. Water column chlorophyll peaked in the spring of 2000 and 2001, and the fall of 2000, with sediment parameters peaking 1 to 3 mo later. The benthic foraminiferal standing crop peaked during the spring of both study years, and showed a large peak in the fall of 2001 dominated by the small-sized foraminifer Fursenkoina pontoni. The data strongly suggest that benthic foraminifera increase in number following phytoplankton blooms when many kinds of sediment organic matter also increase. Foraminiferal biovolume does not necessarily follow this pattern, especially when peaks in standing crop mainly consist of small-sized individuals. Foraminiferal biovolume and standing crop generally increase when the sediment $\mathrm{C}: \mathrm{N}$ ratio increases, suggesting that benthic foraminiferal populations in South San Francisco Bay may be exploiting a detrital food source in addition to recently deposited fresh phytoplankton. Thus, foraminifera are probably quick to exploit sediment organic matter, and may be important remineralizers of nutrients in this system.
\end{abstract}

KEY WORDS: Benthic ecology $\cdot$ Foraminifera $\cdot$ Marine protists $\cdot$ Population dynamics $\cdot$ Food webs $\cdot$ Estuarine ecology $\cdot$ Meiofauna $\cdot$ Organic matter

\section{INTRODUCTION}

Single-celled protists play an important role in marine food webs, and probably have since the Precambrian (Fenchel 1987, Capriulo 1990, Lee \& Anderson 1991, Anderson 1994, Lipps \& Culver 2002). They are of central importance in pelagic ecosystems (the 'microbial loop'), where research has focused almost exclusively on ciliated and flagellated protists (Azam et al. 1983, Sherr \& Sherr 1984, Azam 1998). The ecological roles of protists in benthic food webs are proba- bly equally important, but have received less research attention (Lipps \& Culver 2002).

Foraminifera are amongst the most abundant known protists found in marine habitats, sometimes numbering well over a million $\mathrm{m}^{-2}$ (Lipps 1983, Gooday 1994). They occur in all of the world's oceans from the tropics to the poles, and at all depths. Approximately 4000 extant morphologically defined species are known, of which all but 42 are benthic (Lipps 1983, Culver 1993).

Foraminifera are ecologically important constituents of the benthic meiofauna. Altenbach (1992) estimated 
from laboratory microcosm experiments on deep-sea taxa that benthic foraminifera ingest 6 to $10 \%$ of the total organic flux to the sediment surface. In turn, foraminifera are prey for many marine invertebrates and vertebrates (such as holothuroids, deep-sea scaphopods and coral reef fish), and are the chief food source for some of them (Lipps 1983, 1988, Langer et al. 1995, Lipps \& Culver 2002). Benthic foraminifera are thus a link between low and high trophic levels and are important in the cycling of organic matter and organic carbon (Lipps \& Valentine 1970, Gooday 1992).

In the deep sea, foraminifera respond rapidly to food inputs, possibly even more so than meiofaunal metazoans (Gooday 1994). Deep-sea foraminifera living in areas of both high and low inputs of organic matter exhibit unique metabolic responses, with taxa living in areas of periodic pulses of organic matter able to rapidly change their metabolic response by quickly increasing their ATP turnover rates (Linke 1992). These studies indicate that foraminifera may exploit organic matter more quickly and in a different way than the other meiofauna, and that different species may have different responses to food inputs depending on their natural environment, feeding strategy and energy cycling.

Estuaries are particularly vulnerable to environmental degradation from human activity as many urban areas are located near or adjacent to estuaries (Havens \& Aumen 2000, Rogers \& McCarty 2000, Kennish 2002). Benthic meiofauna, including foraminifera and other non-metazoan organisms, are an often overlooked component of estuarine communities whose populations may be closely linked to environmental fluctuations, and therefore they may be indicators of habitat degradation or useful research tools for monitoring estuarine ecosystems (Yanko et al. 1998, Kennedy \& Jacoby 1999, Boyd et al. 2000, Bresler \& Yanko-Hombach 2000, Coccioni 2000, Hallock 2000, Samir 2000, Schratzberger et al. 2000, Lee et al. 2001, Samir \& El-Din 2001). A better understanding of the relationship between benthic foraminifera and environmental parameters in estuaries will contribute to our knowledge of ecological relationships and environmental change in coastal and estuarine ecosystems (Murray \& Alve 2000).

South San Francisco Bay, California, USA, is a highly seasonal estuarine system characterized by yearly, predictable blooms of primary production in the water column (Cloern 1996). This seasonality makes it an ideal system in which to study the relationships between primary production, organic matter fluxes, and food resources for the benthos. Research has documented increases in growth rates of benthic macroinvertebrates during and following phytoplankton blooms in South San Francisco Bay (Nichols \& Thompson 1985, Thomp- son \& Nichols 1988). No quantitative studies have been done in the bay on the seasonal relationship between primary production, sediment organic matter, and the ecology of benthic meiofauna or benthic protists.

There have been several studies of foraminiferal distributions in San Francisco Bay (McDonald \& Diediker 1930, Bandy 1953, Arnal \& Conomos 1962, Means 1965, Slater 1965, Quinterno 1968, Locke 1971, Arnal et al. 1980). Some of these workers have suggested that organic carbon, salinity, substratum type, and substratum $\mathrm{pH}$ were factors determining the distribution of Rose Bengal stained foraminiferal populations (Quinterno 1968, Arnal et al. 1980). No information on the variability of living foraminiferal populations over time has been available for San Francisco Bay. I present a $2 \mathrm{yr}$, monthly time series of the abundance of Rose Bengal stained foraminifera, environmental parameters, and potential food resources in South San Francisco Bay. The goal of this study was to test the hypothesis that benthic foraminiferal populations in South San Francisco Bay exhibit patterns correlated with seasonal changes in water column primary production and benthic organic matter.

\section{MATERIALS AND METHODS}

Study site. San Francisco Bay is the largest estuary on the Pacific Coast of the Americas, with a surface area of $1240 \mathrm{~km}^{2}$. It is a shallow, turbid embayment with an average depth of only $6 \mathrm{~m}$ at mean lower low water (Conomos et al. 1985). San Francisco Bay consists of 2 hydrologically distinct (but connected) subsystems (Conomos 1979) (Fig. 1): North San Francisco Bay and South San Francisco Bay. South San Francisco Bay (hereafter 'South Bay') is a tidally influenced, partly enclosed lagoon-type estuary which has nearly oceanic salinity in the dry summers that decreases during the high flow winter and spring season. The maximum tidal range in South San Francisco Bay is about $3 \mathrm{~m}$ (United States Geological Survey [USGS] 2003). This study focuses on USGS Stn 25 in South Bay (Fig. 1). Stn 25 has an average depth of $8.8 \mathrm{~m}$ at mean lower low water, and the surface salinity ranges from 15 to 32 PSU from the rainy to the dry season ${ }^{1}$. Stn 25 is close to the San Bruno Shoal, an important bathymetric feature of South Bay that affects the exchange between Central San Francisco Bay and the southern part of South Bay (Fig. 1).

San Francisco Bay experiences pronounced cyclic fluctuations in primary production; South San Fran-

\footnotetext{
${ }^{1}$ Water column data courtesy of San Francisco Bay Water Quality data: USGS, Menlo Park, CA, http://sfbay.wr.usgs. gov/access/wqdata/index.html
} 


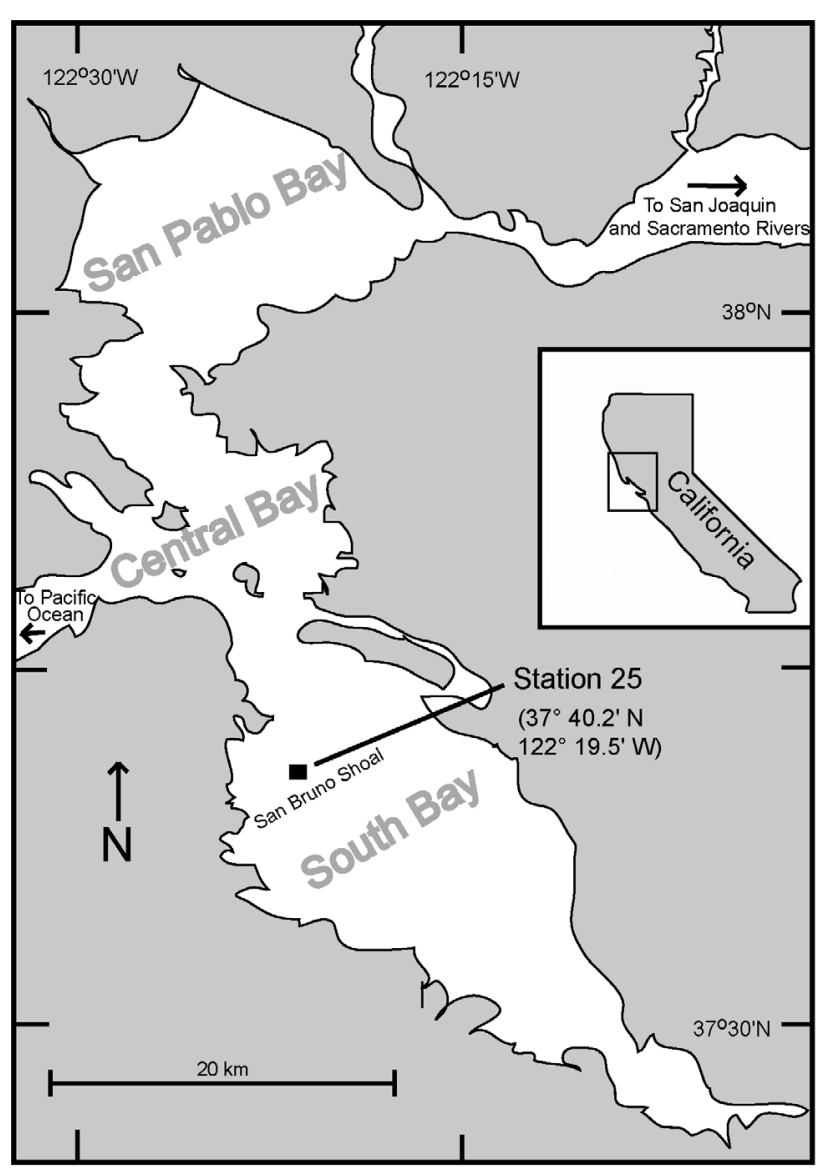

Fig. 1. Map of San Francisco Bay showing location of study site, USGS sampling Stn 25. Sampling site was located in the central channel of the bay

cisco Bay is characterized by marked spring phytoplankton blooms, caused by increased water column stratification after winter rains, and decreased tidal mixing during March and April neap tides (Cloern 1996). These blooms are amongst the most ecologically important characteristics of seasonal cycles in the bay, and have a major effect on the chemical and biological processes in San Francisco Bay (Cloern et al. 1985).

Sampling. Sampling was carried out on monthly cruises for a 2 yr period from November 1999 through November 2001 in cooperation with the United States Geological Survey on the RV 'Polaris' (Table 1).

Water column data were collected using a CTD with sensors for measuring: depth (Paroscientific pressure transducer), conductivity (Sea-Bird Electronics-4 conductivity sensor), temperature (Sea-Bird Electronics-3 thermistor), and chlorophyll (Sea-Tech in vivo fluorometer). Sediment and benthic foraminiferal samples were collected using a $0.10 \mathrm{~m}^{2}$ Van Veen grab. A Van Veen grab was determined to be an appropriate sediment sampler in this study because the depth of sampling was shallow (less than $9 \mathrm{~m}$ ). The sediment-water interface appeared undisturbed and the overlying water was clear when the sediment and foraminiferal samples were taken from the grab.

Collection and analysis of sediment parameters. Five sediment parameters were measured: sediment chlorophyll $a$, sediment bacterial abundance, sediment amino acids, total organic carbon content, and organic nitrogen content of the sediment. The top 1 to $2 \mathrm{~cm}$ of surface sediment was collected from a grab sample at each site. Immediately after collection, aliquots of fresh sediment were homogenized briefly, fixed in diluted formalin, and stored at $4{ }^{\circ} \mathrm{C}$ for later bacterial analysis (Turley \& Hughes 1992, 1994). Additional aliquots of fresh sediment for chlorophyll analysis were stored in the dark at $4^{\circ} \mathrm{C}$, and each sample was processed within $24 \mathrm{~h}$. The remainder of the sediment was frozen at $-20^{\circ} \mathrm{C}$, freeze dried, and stored at room temperature for use in analyses of sedimentary amino acids, total organic carbon (TOC), and organic nitrogen.

Total sediment bacterial abundance was measured using the Acridine Orange, direct-counting method modified from several other studies (Hobbie et al. 1977, Velji \& Albright 1986, Van Duyl \& Kop 1990, Velji \& Albright 1993). Sediment chlorophyll was extracted in acetone using the methods of Levinton \& McCartney (1991) and read on a Turner Design 10-AU fluorometer.

All freeze-dried sediment was sieved through a $500 \mu \mathrm{m}$ sieve before analysis to remove large shell fragments and other debris. Enzyme hydrolyzable amino acid (EHAA) concentrations of sediments were determined using the methods of Mayer et al. (1995). Total sediment organic carbon and nitrogen were determined using a Fisions NA 1500 series $2 \mathrm{CN}$ analyzer using acetanilide and atropine as standards. Sediment was acidified with $0.3 \mathrm{M} \mathrm{HCl}$ to remove carbonates prior to carbon and nitrogen analysis.

Collection and analysis of foraminiferal samples. Samples of the top $1.0 \mathrm{~cm}$ of sediment were collected every month for foraminiferal analysis. Only the upper $1 \mathrm{~cm}$ was sampled after preliminary research at the field sites suggested that the great majority of living foraminifera in this system are found in the upper 1 to $2 \mathrm{~cm}$, and based on other workers' findings that upwards of $71 \%$ of all living foraminifera in the upper $2 \mathrm{~cm}$ of sediment in the field in a cold water/temperate site (Barmawidjaja et al. 1992). Single samples were taken for the first 5 mo of the study, but replicate samples were collected every month thereafter. Foraminiferal samples were collected from the Van Veen grab using a short plastic core tube. The top $1.0 \mathrm{~cm}$ of sediment was sliced from the core and deposited into a jar containing a solution of $10 \%$ formalin (buffered with sodium borate) to which Rose Bengal stain had already been added to a concentration of $1.0 \mathrm{~g} \mathrm{l}^{-1}$. Rose 
Table 1. Sampling dates and number of Rose Bengal-stained benthic foraminifera by species, South Bay Stn 25, November 1999 through November 2001. Each count is a mean of 2 replicates except for November 1999 to March 2000, when replicate samples were not collected

\begin{tabular}{|c|c|c|c|c|c|c|c|c|c|c|c|c|}
\hline Sampling dates & 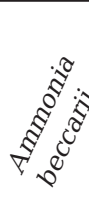 & की & 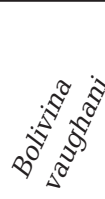 & 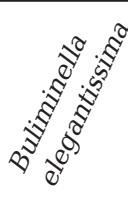 & 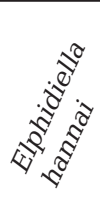 & 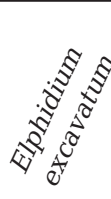 & 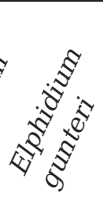 & 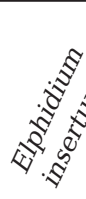 & 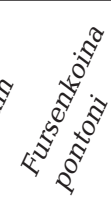 & 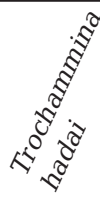 & 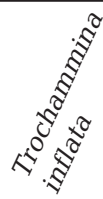 & א. \\
\hline 10-11 Nov 1999 & 10 & 11.25 & 18 & 12 & 1.25 & 0 & 0 & 0 & 0 & 5 & 0 & 57.5 \\
\hline 14-15 Dec 1999 & 10 & 12.5 & 12.75 & 8.5 & 2.5 & 0 & 0 & 0 & 2.5 & 1.25 & 5 & 55 \\
\hline 11-12 Jan 2000 & 15 & 15 & 9.75 & 6.5 & 1.25 & 0 & 0 & 0 & 2.5 & 6.25 & 0 & 56.25 \\
\hline 8-9 Feb 2000 & 15 & 40 & 27 & 18 & 6.25 & 0 & 0 & 0 & 51.25 & 7.5 & 0 & 165 \\
\hline 7-8 Mar 2000 & 12.5 & 53.75 & 25.5 & 17 & 3.75 & 7.5 & 2.5 & 12.5 & 28.75 & 40 & 6.25 & 210 \\
\hline 4-5 Apr 2000 & 20 & 23.5 & 11.7 & 7.8 & 8.5 & 8.5 & 3 & 3 & 22 & 22.5 & 7 & 137.5 \\
\hline 16-17 May 2000 & 8 & 21 & 7.2 & 4.8 & 4.5 & 11 & 3.5 & 7.5 & 10.5 & 25 & 3.5 & 106.5 \\
\hline 13-14 Jun 2000 & 1 & 5.5 & 2.1 & 1.4 & 1 & 2 & 0 & 0.5 & 2 & 9.5 & 0.5 & 25.5 \\
\hline 11-12 Jul 2000 & 12.5 & 16 & 8.4 & 5.6 & 8 & 5 & 2 & 4.5 & 16.5 & 12.5 & 2 & 93 \\
\hline 8-9 Aug 2000 & 7 & 17 & 10.2 & 6.8 & 5.5 & 4 & 3 & 7 & 14.5 & 9.5 & 0.5 & 85 \\
\hline 5-6 Sep 2000 & 5 & 12 & 11.4 & 7.6 & 8 & 4 & 2.5 & 6 & 16.5 & 13 & 3.5 & 89.5 \\
\hline $10-11$ Oct 2000 & 12 & 16.5 & 8.1 & 5.4 & 4 & 3.5 & 7.5 & 3.5 & 10.5 & 19 & 5.5 & 95.5 \\
\hline $7-8$ Nov 2000 & 5.5 & 18 & 10.8 & 7.2 & 3 & 3.5 & 3.5 & 2.5 & 15.5 & 8 & 1.5 & 79 \\
\hline $12-13$ Dec 2000 & 5.5 & 25.5 & 13.5 & 9 & 4.5 & 6 & 10.5 & 3.5 & 31.5 & 14 & 4 & 127.5 \\
\hline 6-7 Feb 2001 & 8.5 & 15 & 14.6 & 27.9 & 5 & 4.5 & 2.5 & 4.5 & 83 & 25.5 & 6.5 & 197.5 \\
\hline 26-27 Feb 2001 & 8 & 2 & 4.8 & 3.2 & 4 & 6 & 5 & 6 & 13 & 33 & 6 & 91 \\
\hline 27-28 Mar 2001 & 6 & 13 & 8.4 & 5.6 & 5 & 9 & 7 & 7 & 25 & 22 & 5 & 113 \\
\hline 24-25 Apr 2001 & 10 & 20 & 8 & 23 & 7 & 4 & 6 & 3 & 62 & 37 & 2 & 182 \\
\hline 2-25 May 2001 & 26 & 15 & 66 & 20 & 9 & 4 & 0 & 4 & 242 & 5 & 0 & 391 \\
\hline 19-20 Jun 2001 & 9 & 16 & 10 & 16 & 2 & 10 & 7 & 4 & 65 & 20 & 3 & 162 \\
\hline 17-18 Jul 2001 & 5 & 6 & 19 & 29 & 5 & 0 & 0 & 0 & 64 & 20 & 2 & 150 \\
\hline 11-12 Sep 2001 & 17 & 51 & 40 & 17 & 0 & 1 & 0 & 0 & 380 & 3 & 0 & 509 \\
\hline $15-16$ Oct 2001 & 1 & 28 & 18 & 3 & 0 & 0 & 0 & 0 & 121 & 0 & 0 & 171 \\
\hline 27-28 Nov 2001 & 2 & 11 & 26 & 0 & 0 & 0 & 0 & 0 & 110 & 0 & 0 & 149 \\
\hline
\end{tabular}

Bengal stain was chosen as the most practical method for determining the presence of live foraminifera for this study because it would produce results that could be compared to other similar studies (Murray 2000). The entire volume of sediment collected for foraminiferal analysis for each replicate was $12.5 \mathrm{~cm}^{3}$.

Each sample was stored at $4^{\circ} \mathrm{C}$ in the laboratory and allowed to stain for $1 \mathrm{wk}$. Each sample was then washed over a $63 \mu \mathrm{m}$ sieve and air dried. While some workers prefer to pick wet samples because the staining is more obvious (Corliss 1985), in this study, dried foraminifera (which can be sorted more quickly) were moistened if there was any question as to the extent of staining. Drying can affect the preservation of softwalled foraminifera. However, in preliminary sampling, in which samples were wet-picked, few, if any, soft-walled forms were found at these sites. Furthermore, drying samples did not affect preservation of agglutinated forms such as Trochammina hadai Uchio. At the beginning of the study, approximately 15 dried samples were floated in sodium polytungstate to separate some of the sediment from the foraminifera. Floatation was abandoned after 15 samples, however, because of the possibility of sample loss due to repeated drying before and after floatation. The remain- der of the 48 total samples processed was counted without flotation. The number of stained foraminifera in each $12.5 \mathrm{~cm}^{3}$ sample was counted. Species diversity was calculated using the $H^{\prime}(S)$ diversity index derived from Shannon-Wiener, and Simpson's index of diversity (1/D) (Simpson 1949, Hill 1973, Murray 1991). Shannon-Wiener is a mean diversity measurement of species composition. The calculation is affected by richness of species and by the distribution of individuals among the species (species composition) (Hill 1973, Murray 1991). The $H^{\prime}(S)$ diversity index, derived from Shannon-Wiener, has been used by other foraminiferal workers in similar studies (Murray 1991), and I used it so this index could be used as a comparison tool between my site and other sites. I used the Simpson's index of diversity because Simpson's index is less sensitive to the presence of rare types, and I felt it important to compare the $H^{\prime}(S)$ index with an index that was less affected by rare taxa (Simpson 1949).

Total biovolume was estimated for each sample by calculating individual test volume using an eyepiece micrometer on a Zeiss microscope (at magnification of 25 to $40 \times$ ) and from scanning electron microscope (SEM) images. As many stained individuals as possible of each species were measured, depending on the 
standing crop of foraminifera in each sample; at least 20 individuals were counted when possible. The unit volumes were calculated, averaged, multiplied by the number of individuals per species, and summed to give total biovolume estimates in $\mathrm{mm}^{3}$ per unit volume sediment (Murray 1973, 1991). Measurements of test and calculations of biovolumes were calculated using the methods of Murray $(1973,1991)$.

\section{RESULTS}

\section{Environmental parameters}

Water column values are averages through the entire water column. Water column temperature ranged from 10 to $20^{\circ} \mathrm{C}$ and salinity ranged from 18 to 32 PSU during the study period (Fig. 2). Salinity was much lower during the rainy season of winter and spring of 2000 than in winter/spring 2001. Mean water column chlorophyll was $7.61 \mathrm{mg} \mathrm{m}^{-3}$ (Fig. 2). As expected, there were peaks in chlorophyll a during the spring bloom period of $15.0 \mathrm{mg} \mathrm{m}^{-3}$ in April 2000 and 30.3 and $13.8 \mathrm{mg} \mathrm{m}^{-3}$ in March and April 2001, respectively (Fig. 2). There was also a phytoplankton bloom in South Bay in fall 2000: water column chlorophyll a levels at Stn 25 were 26.0 and $33.0 \mathrm{mg} \mathrm{m}^{-3}$ in November and December 2000, respectively (Fig. 2).

Peaks in sediment parameters lag peaks in water column chlorophyll a by 1 to 4 mo (Fig. 3). Sediment parameters generally peaked in the spring/ summer, and in fall 2001 (Fig. 3). C:N ratios of sediment ranged from 0.4 to 13.5, with lowest values in late summer and fall 2000 and peaks in the spring of both years (Fig. 4).

\section{Foraminiferal population}

\section{Taxonomy}

All 11 species found in this study are common on the west coast of the USA and have been reported in other studies of California and San Francisco Bay foraminifera (Fig. 5, Table 1) (Lankford \& Phleger 1973, Arnal et al. 1980, McCormick et al. 1994). The samples examined for this study contained a population of hundreds of individuals with morphologies similar to published descriptions of Fursenkoina pontoni (Cushman) (Cushman 1932, 1933, Lankford \& Phleger 1973). However, there were 2 distinct morphotypes in this population, ranging from those characteristic of $F$. pontoni to those characteristic of Hopkinsina pacifica (Cushman) with no discernable break between morphotypes (Fig. 5j,k) (Cushman 1932, 1933, Lankford \& Phleger 1973). I chose to call this population Fursenkoina pontoni (Cushman) to be consistent with other foraminiferal workers in San Francisco Bay; I call the 2 different morphotypes Fursenkoina pontoni forma a and Fursenkoina pontoni forma b (Fig. 5j,k) (see Appendix 1 for further discussion of taxonomy).

\section{Standing crop}

To be consistent with other foraminiferal workers, I use the term 'standing crop' to mean number of individuals per unit volume of sediment. All standing crop numbers reported here are means of 2 replicate samples, except for the first 5 mo of the study (from November 1999 through March 2000), when single samples were collected. Total standing crop ranged from 25.5 to
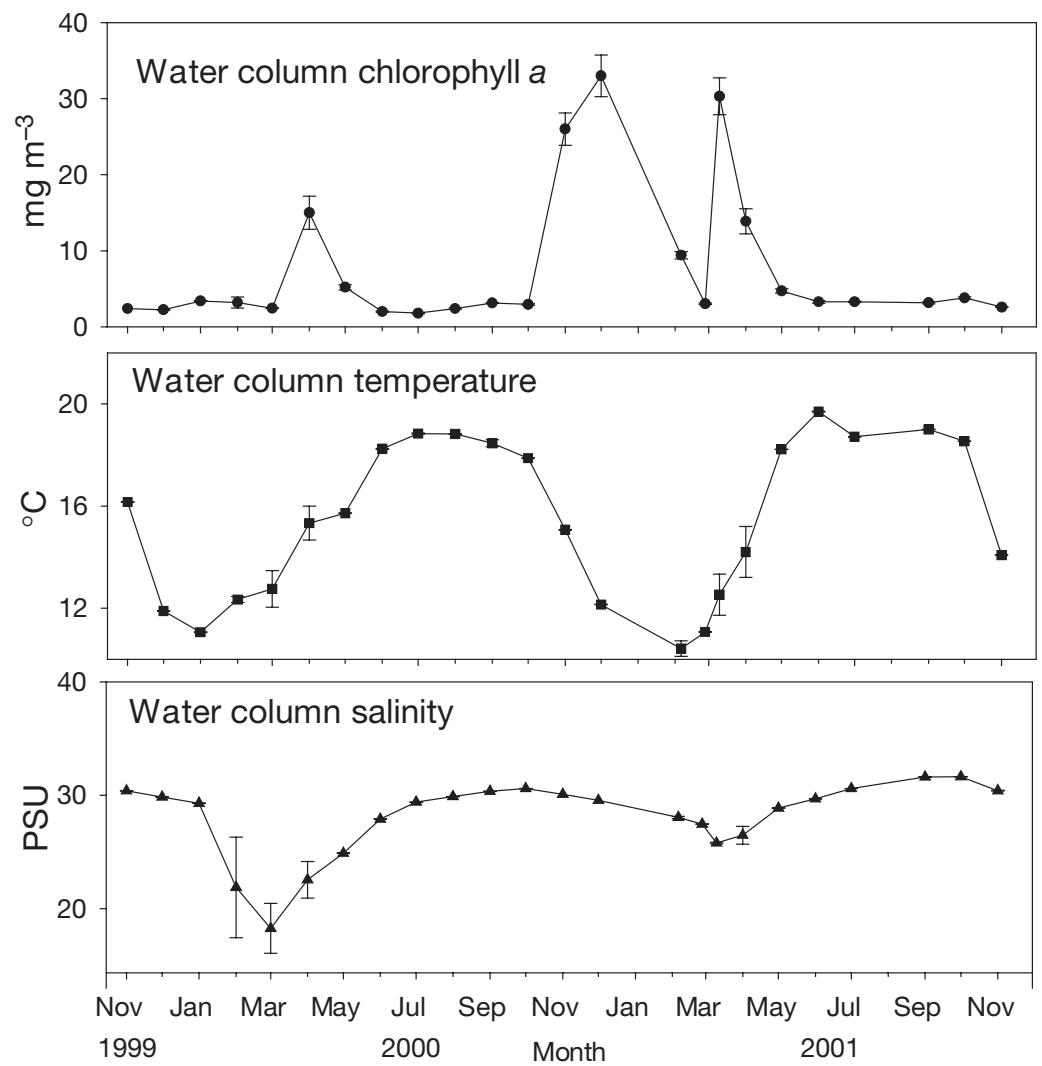

Fig. 2. Water column parameters at USGS Stn 25, South San Francisco Bay, from November 1999 through November 2001. Values are averages through the entire water column 


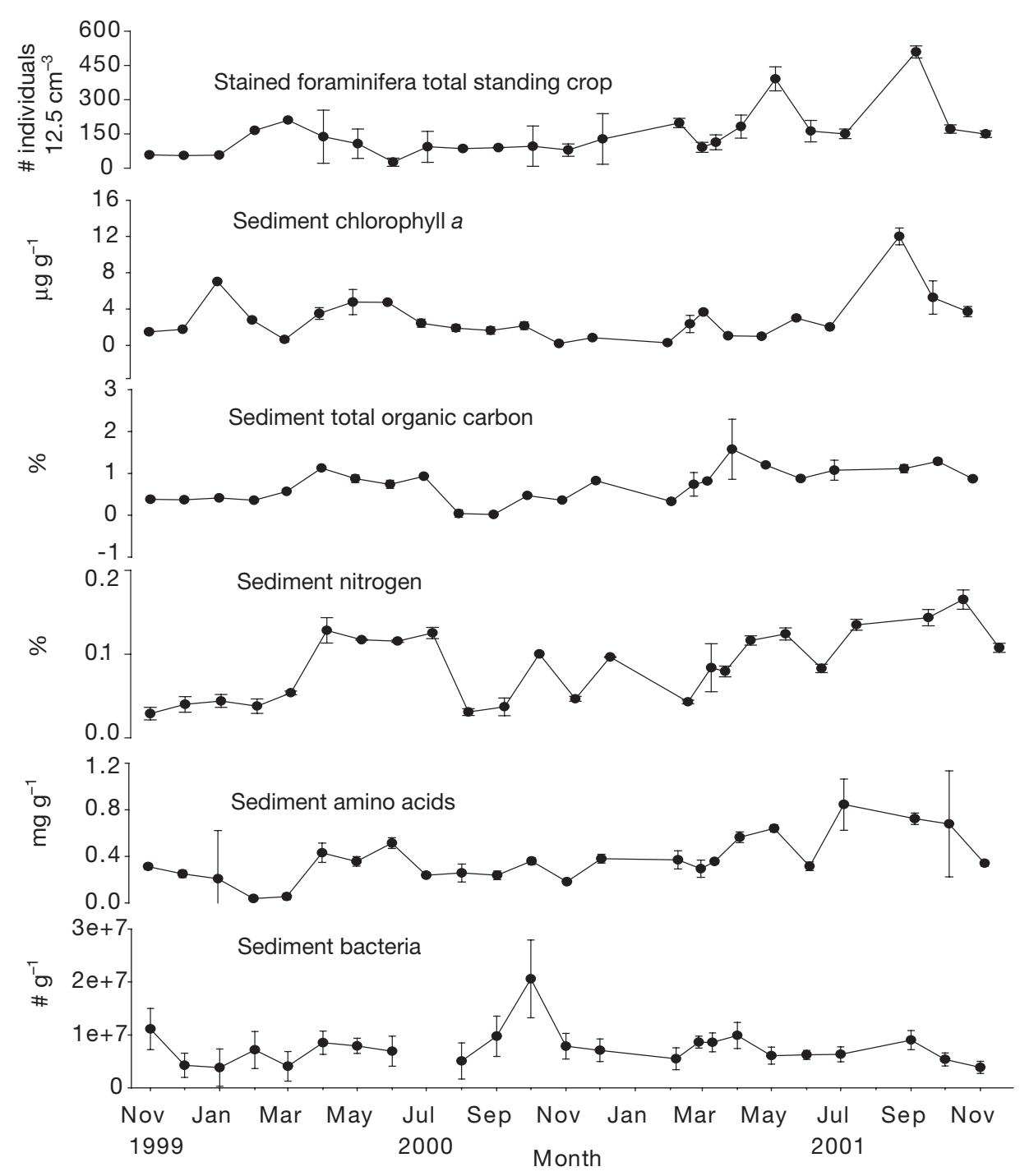

Fig. 3. Total benthic foraminiferal standing crop and sediment parameters at USGS Stn 25, South San Francisco Bay from November 1999 through November 2001

509 ind. per $12.5 \mathrm{~cm}^{3}$, with a mean standing crop of 145.8 ind. per $12.5 \mathrm{~cm}^{3}$ (Table 1, Fig. 4). The total standing crop pattern at Stn 25 showed seasonal cycles: total standing crop peaked during the spring of both study years, and showed a large peak in the fall of 2001 (Fig. 4).

The total standing crop was dominated by Fursenkoina pontoni, which constituted $39 \%$ of all the individuals counted in this study. The other dominant taxa were Bolivina striatula Cushman, B. vaughani Natland, and Trochammina hadai Uchio, at 13, 11 and $10 \%$ of all individuals, respectively. F. pontoni numbers showed repetitive seasonal patterns, with increases in the spring and fall of 2001, with 242 individuals in May 2001 and 380 individuals in September 2001 (Fig. 6). The increase in total standing crop dur- ing these months is largely due to the increase in F. pontoni (Figs. 6 \& 7). B. striatula and B. vaughani also showed repetitive seasonal patterns, with peaks in spring 2000 and 2001 and in fall 2001 (Fig. 6). T. hadai did not have a discernible seasonal pattern, although standing crop also peaked in the spring of both years (Fig. 6). However, in fall 2001, when other dominant taxa increased in standing crop, T. hadai standing crop decreased.

Ammonia beccarii and Bulimiella elegantissima standing crop also showed seasonal patterns. These taxa constituted 7 and $8 \%$ of total individuals, respectively. Both taxa also increased in spring 2000, spring 2001, and fall of 2001 (Fig. 8). In the spring and fall of 2001, all of the stained $A$. beccarii present in the samples were juveniles. 

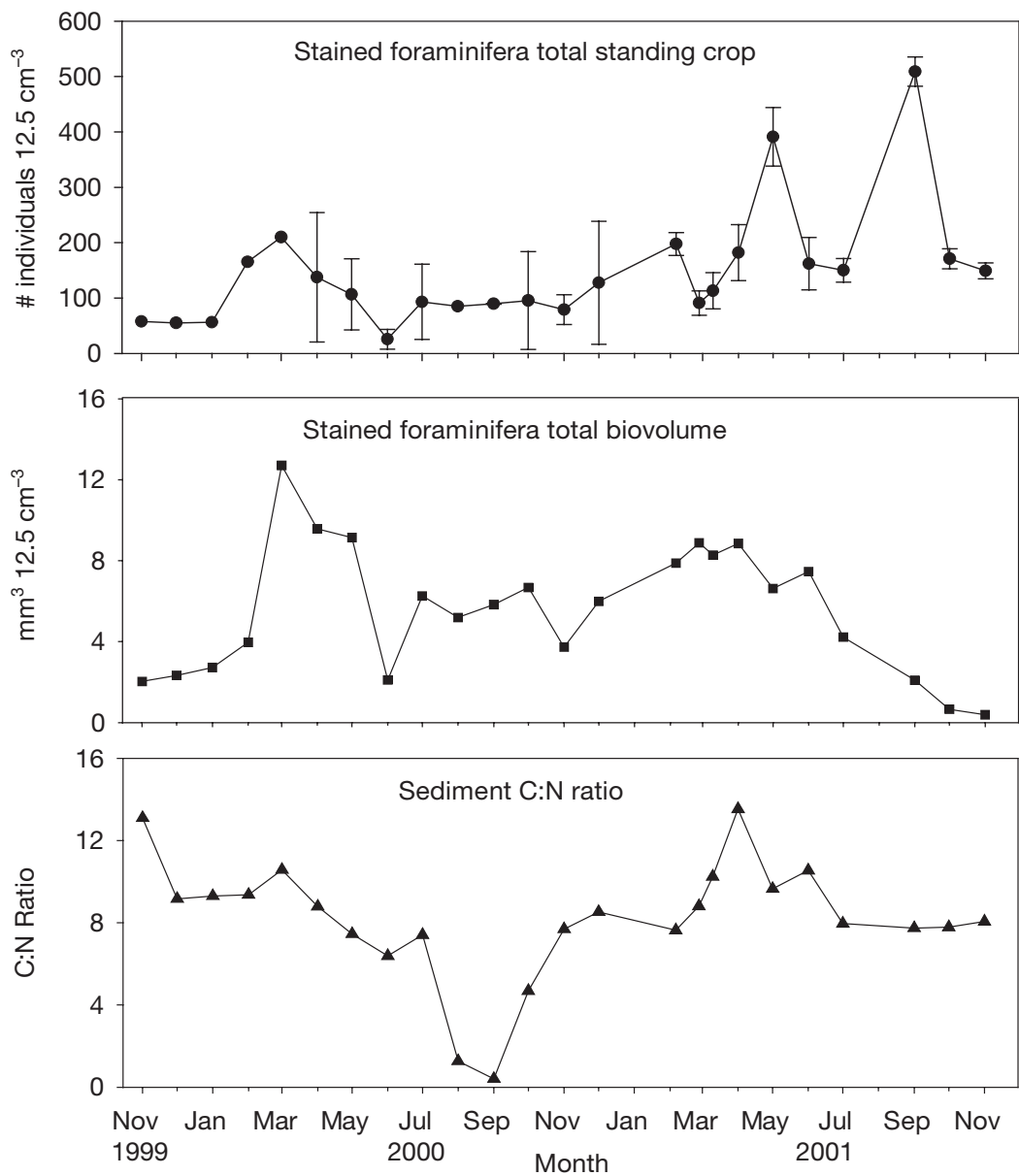

Fig. 4. Total benthic foraminiferal standing crop, total benthic foraminiferal biovolume, and sediment C:N ratio at USGS Stn 25, South San Francisco Bay, November 1999 through November 2001

Biovolume

The mean biovolume for a single individual of each of the dominant taxa were as follows: $0.0015 \mathrm{~mm}^{3}$ for Fursenkoina pontoni; $0.002 \mathrm{~mm}^{3}$ for Bolivina vaughani, $0.0155 \mathrm{~mm}^{3}$ for B. striatula, and $0.130 \mathrm{~mm}^{3}$ for Trochammina hadai. Total biovolume per $12.5 \mathrm{cc}$ sediment for all taxa peaked in the spring during both years, as standing crop did, with highest biovolume in spring 2000 when the population was dominated by larger taxa such as T. hadai and B. striatula (Figs. 4 \& 7). However, the lowest total biovolume occurred in fall 2001 when the highest standing crop values were found, due to the dominance of the small-sized $F$. pontoni during those months.

\section{Species diversity}

Eleven total live species were recorded at Stn 25 during this study (Table 1). Species numbers reached their lowest point in fall 1999 and fall 2001, and reached a plateau between March 2000 and March 2001 (Fig. 9). The $H^{\prime}(S)$ diversity index showed a similar pattern to species numbers; these 2 measures showed significant statistical positive correlation with each other (Pearson correlation, $\alpha=0.05, \mathrm{p} \leq$ 0.001). Simpson's index of diversity $(1 / D)$ also showed a pattern similar to species numbers, except for an increase in Simpson's index between September and November 2001 when species number was decreasing (Fig. 9). Simpson's $1 / D$ index did not show any significant statistical correlation with species diversity or $H^{\prime}(S)$ index.

\section{Relationship between foraminifera and environmental parameters}

Total standing crop and the standing crops of individual taxa did not show any significant statistical correlation with either water column temperature or salinity. Fursenkoina pontoni standing crop was positively correlated with all sediment parameters (median smoothed data) except bacteria; F. pontoni standing crop was significantly statistically correlated with sediment TOC $(\mathrm{p}=0.002)$, sediment total nitrogen $(\mathrm{p}=$ $0.014)$, and sediment amino acids ( $\mathrm{p} \leq$ 0.001) (Table 3, Pearson correlation, $\alpha=0.05$ ). Total foraminiferal biovolume was negatively correlated with water column salinity (Pearson correlation, $\alpha=$ $0.05, \mathrm{p} \leq 0.001$ ). Total foraminiferal standing crop was positively correlated with water column chlorophyll levels (cross correlation analysis, $\alpha=0.05, \mathrm{p} \leq 0.001$ ); total foraminiferal standing crop lagged water column chlorophyll by 5 mo.

The sediment time series and foraminiferal standing crop data were smoothed using a running median smooth and tested the smoothed data for correlations between parameters. Foraminiferal total standing crop was positively correlated with sediment TOC $(\mathrm{p}=0.024)$ and sediment amino acids $(\mathrm{p}=0.023$ ) (Table 2, SYSTAT v. 10.2.01, Pearson correlation, $\alpha=0.05$ ). Biovolume was not correlated with sediment or water column parameters. Foraminiferal standing crop was highest in the spring, coinciding with high $\mathrm{C}: \mathrm{N}$ ratios, and lowest in the summer and fall when $\mathrm{C}: \mathrm{N}$ ratios were also lowest (Fig. 4). However, foraminiferal standing crop was not correlated with sediment $\mathrm{C}: \mathrm{N}$ ratio. Total foraminifera 

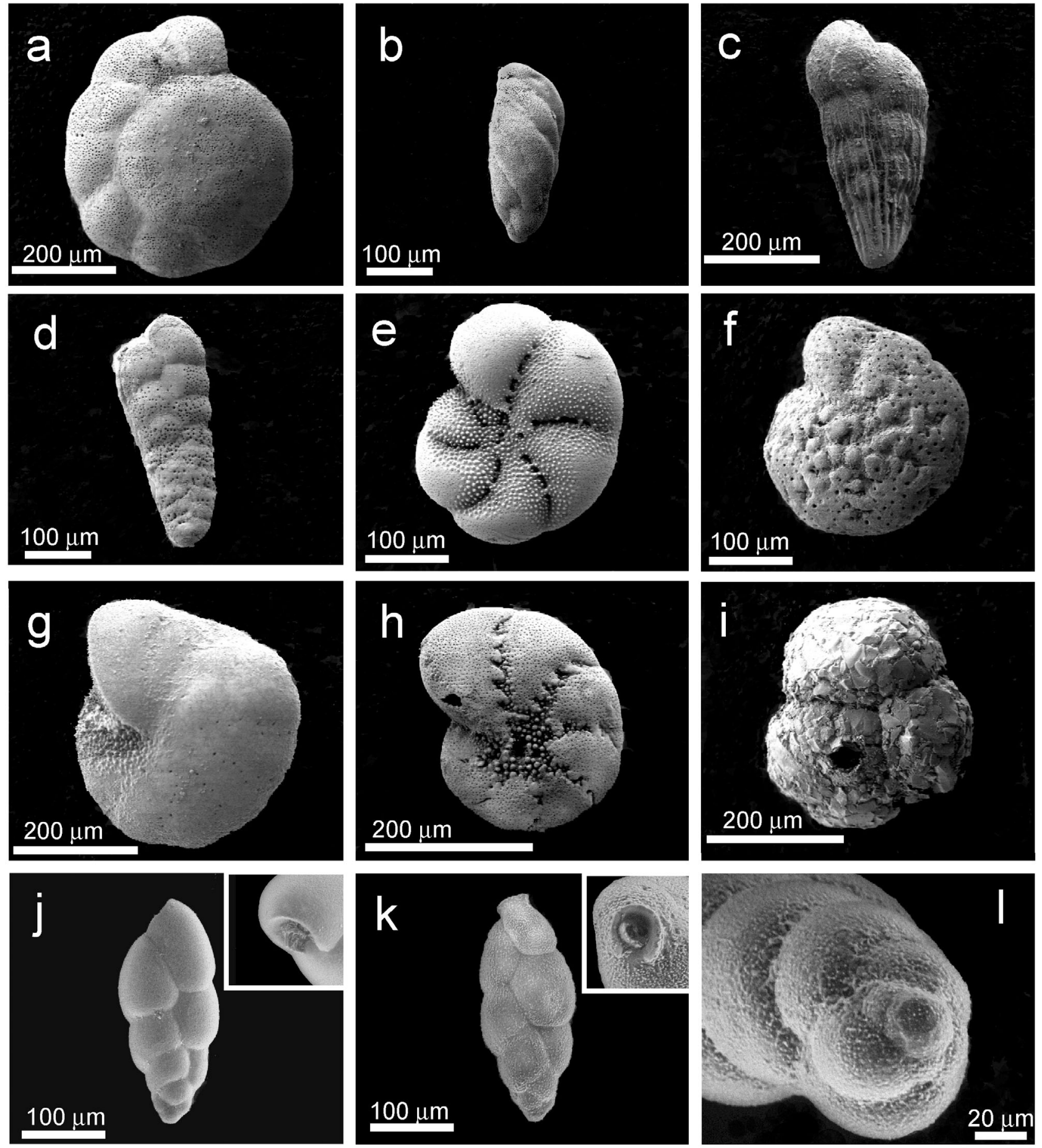

Fig. 5. Scanning electron microscope (SEM) images of foraminifera found in this study: (a) Ammonia beccarii; (b) Buliminella elegantissima; (c) Bolivina striatula; (d) Bolivina vaughani; (e) Elphidium excavatum; (f) Elphidium gunteri; (g) Elphidiella hannai; (h) Elphidium incertum; (i) Trochammina hadai; (j) Fursenkoina pontoni forma a (inset shows detail of the aperture); (k) Fursenkoina pontoni forma $b$ (inset shows detail of the aperture); (l) Fursenkoina pontoni forma $b$, showing triserial arrangement of first chambers. See Appendix 1 for discussion of taxonomic considerations for $F$. pontoni. No unbroken specimens of Trochammina inflata were available to photograph 

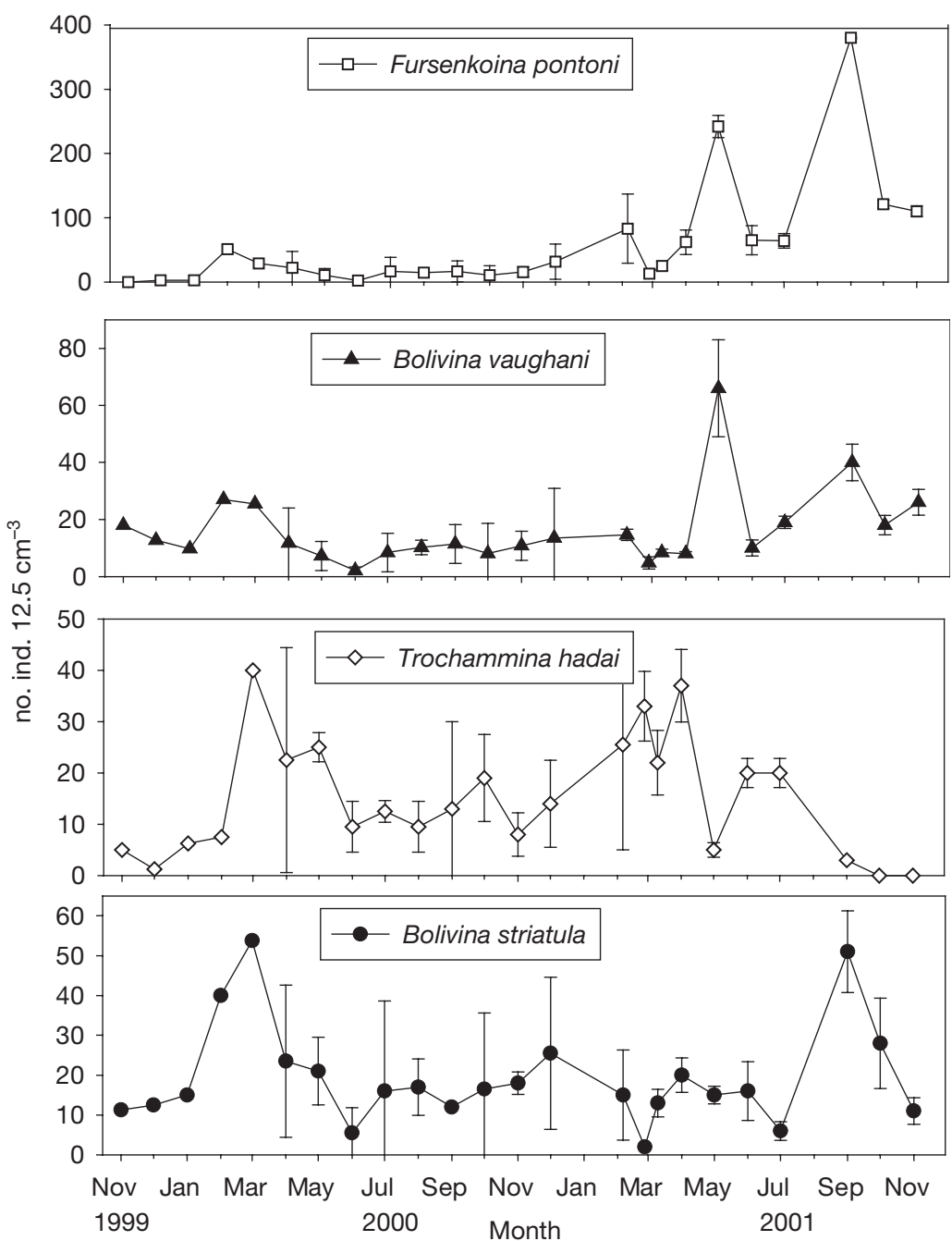

Fig. 6. Standing crop of dominant benthic foraminiferal taxa at USGS Stn 25 in South San Francisco Bay, November 1999 through November 2001 creased 7 -fold in April 2000 and 10-fold in March 2001 (Fig. 2). The fall 2000 data, which reveals a large increase in water column chlorophyll $a$, do not show patterns that are typically observed in South Bay (Cloern 1996). The causes of these extreme chlorophyll peaks in the fall in South Bay are unknown at present. One possible explanation is that high rainfall in October 2000 may have increased water column stratification that resulted in a phytoplankton bloom ${ }^{2}$.

San Francisco Bay is a shallow estuary, and coupling between processes in the water column and benthos has been documented (Nichols \& Thompson 1985, Grenz et al. 2000, Guarini et al. 2002). The seasonality in water column production is also evident in the sediment organic matter data presented here. Sediment chlorophyll $a$, TOC, nitrogen, and amino acids all exhibited seasonal peaks that followed peaks in water column chlorophyll by 2 to 4 mo. Sediment bacterial abundance was more variable and did not exhibit clear seasonal patterns. Many factors affect bacterial populations (Austin \& Findlay 1989), and bacterial abundance is a function of organic matter availability, growth rates, and predation. Bacterial abundance also does not reflect changes in bacterial community composition (Austin \& Findlay 1989). biovolume showed peaks in the spring of both years, at the same time as $\mathrm{C}: \mathrm{N}$ peaks, and biovolume decreased in fall 2001 when C:N reached a plateau (Fig. 4). Foraminiferal biovolume did not show significant statistical correlation with sediment $\mathrm{C}: \mathrm{N}$ ratio.

\section{DISCUSSION}

\section{Environmental seasonality}

The environmental data presented here are characteristic of a seasonal system in terms of both biotic and abiotic factors. There was strong seasonality in water column primary production, which is characteristic of phytoplankton bloom dynamics in South San Francisco Bay (Cloern et al. 1985, Powell et al. 1989, Cloern 1996, Lucas et al. 1999). Water column chlorophyll a in-
Table 2. Pearson correlations between stained foraminiferal total standing crop and water column and sediment parameters (median-smoothed data) at South Bay Stn 25, with Bonferroni adjusted probabilities. SYSTAT v. 10.2.01. ${ }^{*}$ Correlations significant at $\alpha=0.05$. Note that the correlation between foraminiferal standing crop and water column chlorophyll a $(\mathrm{chl}$ a) represents a 5 mo time lag. TOC: total organic carbon; EHAA: enzyme hydrolyzable amino acid

\begin{tabular}{|lrc|}
\hline & $\mathrm{r}$ & $\mathrm{p}$ \\
\hline Sediment bacteria & -0.223 & 1.000 \\
Sediment TOC & 0.609 & $0.024^{*}$ \\
Sediment nitrogen & 0.499 & 0.196 \\
Sediment EHAA & 0.611 & $0.023^{*}$ \\
Sediment chl $a$ & 0.080 & 1.000 \\
Water column chl a & 0.804 & $\leq 0.001^{*}$ \\
\hline
\end{tabular}

\footnotetext{
${ }^{2}$ Rainfall data courtesy of the National Weather Service, Western Regional Climate Center, Reno, NV, USA
} 


\section{Foraminiferal population and environmental parameters}

Previous studies have documented links between benthic foraminiferal populations and cycles in food supply and/or levels of organic matter, and have found evidence that benthic foraminifera are efficient at quickly exploiting food resources, both in shallow and deep water environments (Buzas 1969, Lee \& Muller 1973, Arnal et al. 1980, Erskian \& Lipps 1987, Alve \& Murray 1994, Kitazato \& Ohga 1995, Ohga \& Kitazato 1997, Altenbach \& Struck 2001, Murray 2001). Foraminiferal populations have been shown to increase in response to blooms in primary production (Lee et al. 1966, Lee \& Muller 1973, Erskian \& Lipps 1987, Alve \& Murray 1994). In South San Francisco Bay, I found that both total foraminiferal standing crop and the standing crops of individual taxa (and to a lesser extent, total biovolume) exhibit seasonal cycles similar to those of sediment organic matter levels. Fluctuations in benthic foraminiferal populations in this system appear to be closely tied to cycles in food resources. The data strongly suggest that foraminifera are important consumers of sediment organic matter in this system, and may play a significant role in remineralizing nutrients in the San Francisco Bay benthos.

Total foraminiferal standing crop was positively correlated both with water column chlorophyll (with a time lag) and sediment TOC. Therefore the question remains: are benthic foraminifera at this site feeding on organic matter of water column origin, or organic matter produced in situ by benthic macroalgae, or both? C:N ratios can give us some information about the quality of this sediment organic matter. Fresh material has lower $\mathrm{C}: \mathrm{N}$ ratios than detrital material (fresh phytoplankton usually has a ratio of approximately 7.0 to 7.5 , while detritus usually has a C:N of 20 to 30) (Hedges et al. 1988). The highest sediment C:N ratios occurred during or after spring or fall phytoplankton blooms, and the lowest C:N ratios occurred during times of low water column chlorophyll levels (Figs. 2 \& 4). This suggests that material sedimented to the benthos following phytoplankton blooms is not fresh material and was reworked in the water column. San Francisco Bay in general is known to be a lightlimited system (Cloern 1996). The samples for this study were collected in the deeper channel, so it is likely that all the chlorophyll $a$ in channel sediments is the result of sedimentation from the water column, rather than in situ production by benthic microalgae. Nichols \& Thompson's (1985), study of benthic microalgae found that the benthic microalgal assemblage was comprised largely of phytoplankton cells that settled to the bottom following the South Bay bloom, supporting the idea that water column is the source of benthic chlorophyll to channel sediments. This suggests that benthic foraminifera in San Francisco Bay may be exploiting a food resource consisting largely of detrital, water column derived material.

In searching for 1 environmental parameter that may be measured to represent available food sources for benthic foraminifera, many workers have investigated the correlation between foraminiferal populations and sediment TOC, but some investigators have found poor correlation between foraminiferal abundance and organic carbon (Setty \& Nigam 1982, Qvale \& Van Weering 1985, Alve \& Murray 1997). Other workers have suggested that measuring sediment chlorophyll may be the best proxy for food supply (Buzas 1969, Erskian \& Lipps 1987, Altenbach \& Sarnthein 1989, Murray \& Alve 2000). Some workers have measured multiple potential food resources including sediment amino acids (Kroencke et al. 2000). Many different food sources and feeding strategies have been reported for benthic foraminifera, including selective ingestion of bacteria, deposit feeding, suspension feeding, detritivory and scavenging, and update of dissolved organic material (Muller \& Lee 1969, Delaca 1982, Lipps 1983, Goldstein \& Corliss 1994). Therefore, a wide range of organic matter types are potential food resources for benthic foraminifera, and different types of food are probably important to benthic foraminifera in different marine environments and at different times of year. In this study, total standing crop was positively correlated with sediment TOC and amino acids (Table 2), and the standing crop of Fursenkoina pontoni was positively correlated with TOC, total nitrogen, and amino acids (Table 3 ). These results suggest that measurement of as many potential food resources as possible are needed to gain a total picture of food supply for benthic foraminifera.

In the present study, peaks in foraminiferal standing crop and biovolume in San Francisco Bay coincided with changes in water column temperature and decreases in water column salinity (Figs. 2 \& 4); biovolume was statistically negatively correlated with salinity. Therefore, the direct or indirect influence of abiotic environmental factors cannot be ruled out. In a non-seasonal study of foraminiferal distribution in San Francisco Bay, Arnal et al. (1980) suggested that salinity was a factor influencing the distributions of Buliminella elegantissima, Hopkinsina pacifica, and perhaps Bolivina vaughani. Jones \& Ross (1979) measured 11 environmental parameters and found that foraminiferal populations in Samish Bay, Washington, USA, showed a significant statistical relationship with water temperature, salinity, total dissolved phosphates, dissolved nitrogen, and substrate type. This suggests that investigating many different lines of evidence (includ- 
Table 3. Pearson correlations between standing crop of stained Fursenkoina pontoni and sediment and water column parameters (median-smoothed data) at South Bay Stn 25, with Bonferroni adjusted probabilities. SYSTAT v. 10.2.01. ${ }^{*}$ Correlations significant at $\alpha=0.05$

\begin{tabular}{|lrc|}
\hline & $\mathrm{r}$ & $\mathrm{p}$ \\
\hline Sediment bacteria & -0.266 & 1.000 \\
Sediment TOC & 0.726 & $0.002^{*}$ \\
Sediment nitrogen & 0.665 & $0.014^{*}$ \\
Sediment EHAA & 0.835 & $\leq 0.001^{*}$ \\
Sediment chl $a$ & 0.195 & 1.000 \\
Water column chl a & -0.081 & 0.708 \\
\hline
\end{tabular}

ing both water column and sediment parameters, biotic and abiotic factors) may be the most effective research methodology.

\section{Comparisons of patterns in dominant taxa}

Fursenkoina pontoni was dominant in terms of total individuals over the entire study. Its dominance increased from being approximately 10 to $20 \%$ of all individuals between December 1999 and December 2000 , to being as much as $75 \%$ of all individuals after February 2001 (Fig. 7). This increase in percentage coincided with very large fall 2000 and spring 2001 phytoplankton blooms that deposited a large amount of organic matter in the sediment and resulted in a sustained increase in sediment organic matter and $\mathrm{C}: \mathrm{N}$ ratio (Figs. $3 \& 4$ ). In other studies, Fursenkoina populations have been linked with pollution, high organics, and low oxygen levels (Seiglie 1974, Setty \& Nigam 1983, Resig et al. 1995). Benthic foraminiferal population distributions have been linked to interstitial dissolved oxygen levels (Shiba 1986, Levin et al. 1991,
Moodley \& Hess 1992, Moodley et al. 1993. In this system, as in other environments, high levels of sediment organic matter may increase microbial activity in the sediment and thus result in a decrease in pore water dissolved oxygen concentrations (Upton 1993). I did not measure sediment pore-water dissolved oxygen levels, so I cannot differentiate between an F. pontoni response to high organic matter levels versus low dissolved oxygen levels. Other species found at this site have not been linked with low dissolved oxygen levels. Thus, the fact that most other dominant species also increased coincidentally with $F$. pontoni lends support to the hypothesis that organic matter levels (not low oxygen levels) were responsible for the standing crop increase.

In September 2001, when sediment chlorophyll a levels were the highest for the whole study, Fursenkoina pontoni increased dramatically. Bolivina vaughani and B. striatula increased as well (Fig. 6). However, Trochammina hadai decreased in September 2001 and then disappeared from samples altogether in October and November 2001 (Fig. 6). T. hadai is an exotic species that was introduced to San Francisco Bay from Japan by unknown anthropogenic means, and has become extremely abundant at some sites in the bay, possibly contributing to the decline of other, native foraminiferal taxa (McGann \& Sloan 1996, McGann et al. 2000). F. pontoni numbers were relatively low until a huge increase in 2001. F. pontoni may have slow rates of population growth until there is a pulse of food, or may be able to quickly exploit blooms of production or increase in numbers rapidly when environmental conditions are optimal, as has been found with some other foraminiferal taxa (Matera \& Lee 1972, Lee \& Muller 1973, Linke et al. 1995). However, the decline of T. hadai in this study in fall 2001 indicates that it may be outcompeted under some circumstances. Other
Fig. 7. Relative abundance (\% of total individuals) of dominant benthic foraminiferal taxa at USGS Stn 25, South San Francisco Bay, November 1999 through November 2001

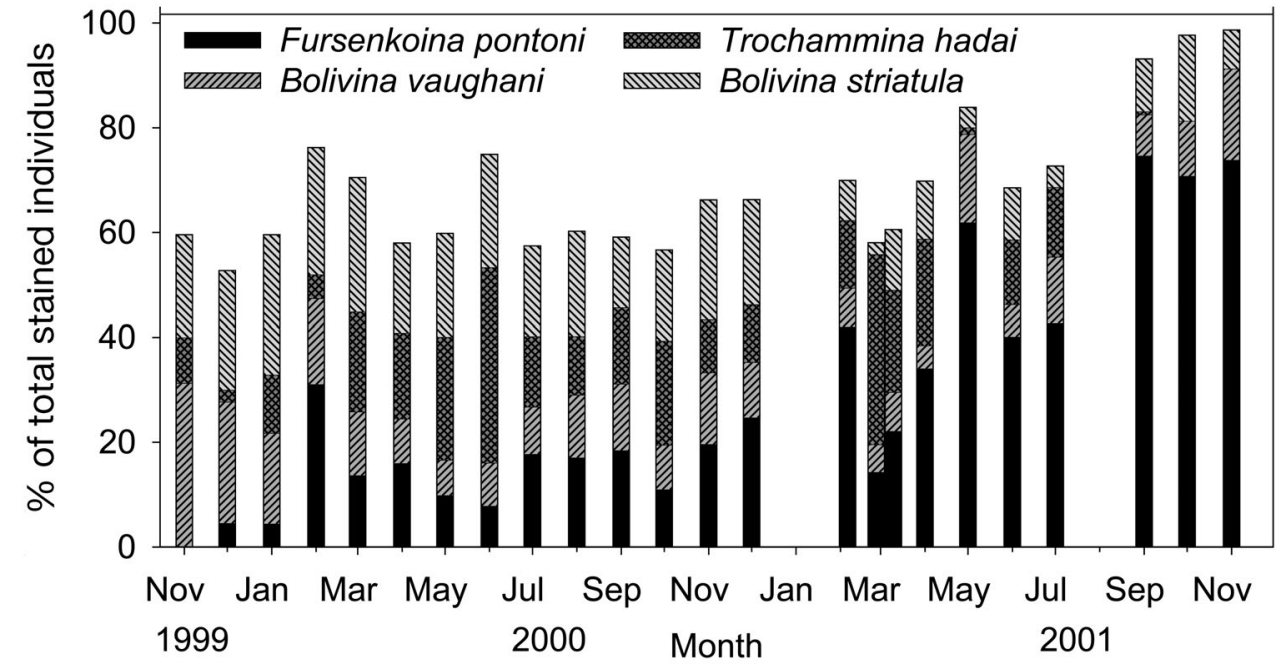



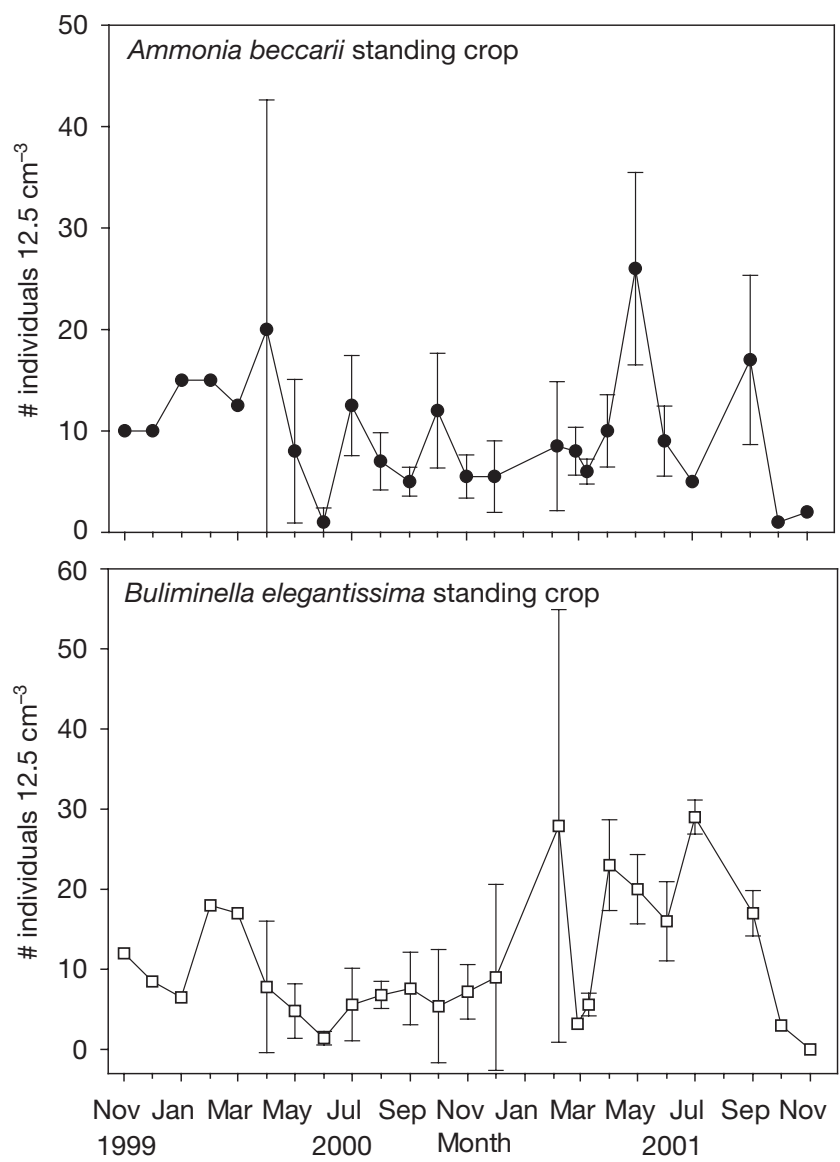

Fig. 8. Standing crops of Ammonia beccarii and Buliminella elegantissima at USGS Stn 25, South San Francisco Bay, November 1999 through November 2001

studies on the west coast of the USA have found that some foraminiferal taxa bloom at certain times of year (Jones \& Ross 1979). In a similar study in a Swedish fjord ecosystem, Stainforthia fusiformis (which is morphologically very similar to $F$. pontoni), increased in population by 7 times during 1 mo following food input from the spring phytoplankton bloom. (Gustafsson \& Nordberg 2001).

\section{CONCLUSIONS}

Data are presented here from a 2 yr, monthly study of stained benthic foraminiferal populations, along with water column chlorophyll and sediment organic matter abundance, in South San Francisco Bay. The data strongly suggest that benthic foraminifera increase in numbers following phytoplankton blooms when many kinds of sediment organic matter also increase. Foraminiferal biovolume does not necessarily follow this pattern, especially when peaks in standing crop mainly consist of small-sized individuals. Previous



Fig. 9. Species diversity at USGS Stn 25 in South San Francisco Bay, November 1999 through November 2001. (a) Number of species and $H^{\prime}(S)$ diversity index, (b) Number of species and Simpson diversity index $(1 / D)$

work suggests that benthic organic matter in the San Francisco Bay channel is sedimented from the water column; this, along with $\mathrm{C}: \mathrm{N}$ ratios of the sediment, suggests that these benthic foraminiferal populations are exploiting a detrital food source. Thus, foraminifera are probably quick to exploit sediment organic matter, and may be important remineralizers of nutrients in this system. More research is needed to investigate the ecological and physiological processes underlying the patterns documented here in foraminiferal populations. Future benthic foraminiferal research needs include laboratory experiments on feeding, research into environmental optima for each taxon, and work on metabolic and physiological ecology.

Acknowledgements. Many thanks to J. H. Lipps, D. Penry, M. McGann, and D. Sloan, for guidance on carrying out this $\mathrm{PhD}$ research. Special thanks to the scientific staff at the USGS Menlo Park, CA, and the crew of the RV 'Polaris' for generous research collaboration. Thanks to V. Bertics, C. Tran, K. Peeren, and many other lab assistants for invaluable research help. M. McGann provided the funds and facil- 
ities for the SEM work. I acknowledge funding from: (1) the Department of Integrative Biology and the Museum of Paleontology (UCMP) at the University of California, Berkeley, (2) the Geological Society of America, (3) the Paleontological Society, (4) the Cushman Foundation for Foraminiferal Research. This is UCMP contribution \#1858.

\section{LITERATURE CITED}

Altenbach AV (1992) Short-term processes and patterns in the foraminiferal response to organic flux rates. Mar Micropaleontol 19:119-129

Altenbach AV, Sarnthein M (1989) Productivity record in benthic foraminifera. In: Berger WH, Smetacek V, Wefer G (eds) Productivity of the ocean: present and past. Wiley, Chichester, p 255-269

Altenbach AV, Struck U (2001) On the coherence of organic carbon flux and benthic foraminiferal biomass. J Foraminifer Res 31:79-85

Alve E, Murray JW (1994) Ecology and taphonomy of benthic foraminifera in a temperate mesotidal inlet. J Foraminifer Res 24:18-27

Alve E, Murray JW (1997) High benthic fertility and taphonomy of foraminifera: a case study of the Skagerrak, North Sea. Mar Micropaleontol 31:157-175

Anderson OR (1994) The trophic role of planktonic foraminifera and radiolaria. Mar Microb Food Webs 7:31-51

Arnal RE, Conomos TJ (1962) Sedimentary and foraminiferal aspects of southern San Francisco Bay. Geol Soc Am Spec Pap 73:21-22

Arnal RE, Quinterno PJ, Conomos TJ, Gram R (1980) Trends in the distribution of recent foraminifera in San Francisco Bay. Cushman Found Foraminifer Res Spec Publ 19:7-39

Austin HK, Findlay SE (1989) Benthic bacterial biomass and production in the Hudson River Estuary, New York, USA. Microb Ecol 18:105-116

Azam F (1998) Microbial control of oceanic carbon flux: the plot thickens. Science 280:694-696

Azam F, Fenchel T, Field JG, Gray JS, Meyer-Reil LA, Thingstad $F$ (1983) The ecological role of water column microbes in the sea. Mar Ecol Prog Ser 10:257-264

Bandy OL (1953) Ecology and paleoecology of some California foraminifera, Part I. J Paleontol 27:161-182

Barmawidjaja DM, Jorissen FJ, Puskaric S, Van der Zwaan GJ (1992) Microhabitat selection by benthic foraminifera in the northern Adriatic Sea. J Foraminifer Res 22:297-317

Boyd SE, Rees HL, Richardson CA (2000) Nematodes as sensitive indicators of change at dredged material disposal sites. Estuar Coast Shelf Sci 51:805-819

Bresler VM, Yanko-Hombach VV (2000) Chemical ecology of foraminifera: parameters of health, environmental pathology, and assessment of environmental quality. In: Martin RE (ed) Topics in geobiology. Environmental micropaleontology: the application of microfossils to environmental geology, Vol 15. Plenum, New York, p 217-254

Buzas MA (1969) Foraminiferal species densities and environmental variables in an estuary. Limnol Oceanogr 41:411-422

Capriulo GM (ed) (1990) Ecology of marine protozoa. Oxford University Press, New York

Cloern JE (1996) Phytoplankton bloom dynamics in coastal ecosystems: a review with some general lessons from sustained investigation of San Francisco Bay, California. Rev Geophys 34:127-168

Cloern JE, Cole BE, Wong RLJ, Alpine AE (1985) Temporal dynamics of estuarine phytoplankton: a case study of San Francisco Bay. Hydrobiologia 129:153-176
Coccioni R (2000) Benthic foraminifera as bioindicators of heavy metal pollution: a case study from the Goro Lagoon (Italy). In: Martin RE (ed) Topics in geobiology. Environmental micropaleontology: the application of microfossils to environmental geology, Vol 15. Plenum, New York, p 71-103

Conomos TJ (ed) (1979) San Francisco Bay: the urbanized estuary. Pacific Division of the American Association for the Advancement of Science, San Francisco, CA

Conomos TJ, Smith RE, Gartner JW (1985) Environmental setting of San Francisco Bay, California, USA. Hydrobiologia 129(1):1-12

Corliss BH (1985) Microhabitats of benthic foraminifera within deep-sea sediments. Nature 314:435-438

Culver SJ (1993) Foraminifera. In: Lipps JH (ed) Fossil prokaryotes and protists. Blackwell Scientific Publications, Boston, MA, p 203-248

Cushman JA (1932) Notes on the genus Virgulina. Contrib Cushman Found Foraminifer Res 8(1):7-23

Cushman JA (1933) Some new recent foraminifera from the tropical Pacific. Contrib Cushman Found Foraminifer Res 9(4):77-95

Delaca TE (1982) Use of dissolved amino acids by the foraminifer Notodendrodes antarctikos. Am Zool 22:683-690

Erskian MG, Lipps JH (1987) Population dynamics of the foraminiferan Glabratella ornatissima (Cushman) in northern California (USA). J Foraminifer Res 17:240-256

Fenchel T (1987) Ecology of protozoa: the biology of free-living phagotrophic protists. Science Tech Publishers, Madison, WI

Goldstein ST, Corliss BH (1994) Deposit feeding in selected deep-sea and shallow-water benthic foraminifera. DeepSea Res Part I Oceanogr Res Pap 41:229-241

Gooday AJ (1992) The role of benthic foraminifera in deepsea food webs and carbon cycling. Eur J Protistol 28:341

Gooday AJ (1994) The biology of deep-sea foraminifera: a review of some advances and their applications in paleoceanography. Palaios 9:14-31

Grenz C, Cloern JE, Hager SW, Cole BE (2000) Dynamics of nutrient cycling and related benthic nutrient and oxygen fluxes during a spring phytoplankton bloom in South San Francisco Bay (USA). Mar Ecol Prog Ser 197:67-80

Guarini JM, Cloern JE, Edmunda J, Gros P (2002) Microphytobenthic potential productivity estimated in three tidal embayments of the San Francisco Bay: a comparative study. Estuaries 25:409-417

Gustafsson M, Nordberg K (2001) Living (stained) benthic foraminiferal response to primary production and hydrography in the deepest part of the Gullmar Fjord, Swedish west coast, with comparisons to Hoglund's 1927 material. J Foraminifer Res 31:2-11

Hallock P (2000) Symbiont-bearing foraminifera: harbingers of global change? Micropaleontology (NY) 46:95-104

Havens KE, Aumen NG (2000) Hypothesis-driven experimental research is necessary for natural resource management. Environ Manag 25:1-7

Hedges JI, Clark WA, Cowie GL (1988) Organic matter sources to the water column and surficial sediments of a marine bay. Limnol Oceanogr 33:1116-1136

Hill MO (1973) Diversity and evenness: a unifying notation and its consequences. Ecology 54:427-432

Hobbie JE, Daley RJ, Jasper S (1977) Use of Nuclepore filters for counting bacteria by fluorescence microscopy. Appl Environ Microbiol 33:1225-1228

Jones GD, Ross CA (1979) Seasonal distribution of foraminifera in Samish Bay, Washington. J Paleontol 53:245-257

Kennedy AD, Jacoby CA (1999) Biological indicators of marine environmental health: meiofauna - a neglected benthic component? Environ Monitor Assess 54:47-68 
Kennish MJ (2002) Environmental threats and environmental future of estuaries. Environ Conserv 29:78-107

Kitazato H, Ohga T (1995) Seasonal changes in deep-sea benthic foraminiferal populations: results of long-term observations at Sagami Bay, Japan. In: Sakai H, Nozaki Y (eds) Biogeochemical processes and ocean flux in the Western Pacific. Terra Scientific Publishing, Tokyo, p 331-342

Kroencke I, Vanreusel A, Vincx M, Wollenburg J, Mackensen A, Liebezeit G, Behrends B (2000) Different benthic size-compartments and their relationship to sediment chemistry in the deep Eurasian Arctic Ocean. Mar Ecol Prog Ser 199:31-41

Langer MR, Lipps JH, Moreno G (1995) Predation on foraminifera by the dentaliid deep-sea scaphopod Fissidentalium megathyris. Deep-Sea Res Part I Oceanogr Res Pap 42: 849-857

Lankford RR, Phleger FB (1973) Foraminifera from the nearshore turbulent zone, western North America. J Foraminifer Res 3:101-132

Lee JJ, Anderson OR (1991) Biology of foraminifera. Academic Press, London

Lee JJ, Muller WA (1973) Trophic dynamics and niches of salt marsh foraminifera. Am Zool 13:215-223

Lee JJ, McEnery M, Pierce S, Freudenthal HD, Muller WA (1966) Tracer experiments in feeding littoral foraminifera. J Protozool 13:659-670

Lee MR, Correa JA, Castilla JC (2001) An assessment of the potential use of the nematode to copepod ratio in the monitoring of metals pollution. The Chanaral case. Mar Pollut Bull 42:696-701

Levin LA, Huggett CL, Wishner KF (1991) Control of deep-sea benthic community structure by oxygen and organicmatter gradients in the eastern Pacific Ocean. J Mar Res 49:763-800

Levinton JS, McCartney M (1991) Use of photosynthetic pigments in sediments as a tracer for sources and fates of macrophyte organic matter. Mar Ecol Prog Ser 78:87-96

Linke P (1992) Metabolic adaptations of deep-sea benthic foraminifera to seasonally varying food input. Mar Ecol Prog Ser 81:51-63

Linke P, Altenbach AV, Graf G, Heeger T (1995) Response of deep-sea benthic foraminifera to a simulated sedimentation event. J Foraminifer Res 25:75-82

Lipps JH (1983) Biotic interactions in benthic foraminifera. In: Trevesz MJS, McCall PL (eds) Biotic interactions in recent and fossil benthic communities. Plenum Press, New York, p 331-376

Lipps JH (1988) Predation on foraminifera by coral reef fish: Taphonomic and evolutionary implications. Palaios 3: 315-326

Lipps JH, Culver SJ (2002) The trophic role of marine microorganisms through time. Paleontolog Soc Pap 8:69-92

Lipps JH, Valentine JW (1970) The role of foraminifera in the trophic structure of marine communities. Lethaia 3:279-286

Locke JL (1971) Sedimentation and foraminiferal aspects on the recent sediments of San Pablo Bay. Master's thesis, San Jose State University, San Jose, CA

Loeblich AR, Tappan H (1987) Foraminiferal genera and their classification, Vol 1-2. Van Nostrand Reinhold, New York

Lucas LV, Koseff JR, Cloern JE, Monismith SG, Thompson JK (1999) Processes governing phytoplankton blooms in estuaries. I: the local production-loss balance. Mar Ecol Prog Ser 187:1-15

Matera NJ, Lee JJ (1972) Environmental factors affecting the standing crop of foraminifera in sublittoral and psammolittoral communities of a Long Island salt marsh. Mar Biol 14:89-103
Mayer LM, Schick LL, Sawyer T, Plante CJ, Jumars PA, Self RL (1995) Bioavailable amino acids in sediments: a biomimetic, kinetics-based approach. Limnol Oceanogr 40: $511-520$

McCormick JM, Severin KP, Lipps JH (1994) Summer and winter distribution of foraminifera in Tomales Bay, northern California. Contrib Cushman Found Foraminifer Res Spec Publ 32:69-101

McDonald JA, Diediker PL (1930) A preliminary report on the foraminifera of San Francisco Bay, California. Micropaleontol Bull 2:33-37

McGann M, Sloan D (1996) Recent introduction of the foraminifer Trochammina hadai Uchio into San Francisco Bay, California, USA. Mar Micropaleontol 28:1-3

McGann M, Sloan D, Cohen AN (2000) Invasion by a Japanese marine microorganism in western North America. Hydrobiologia 421:25-30

Means KD (1965) Sediments and foraminifera of Richardson Bay, California. Master's thesis, University of Southern California, Los Angeles, CA

Moodley L, Hess C (1992) Tolerance of infaunal benthic foraminifera for low and high oxygen concentrations. Biol Bull (Woods Hole) 183:94-98

Moodley L, Troelstra SR, Van Weering TCE (1993) Benthic foraminiferal response to environmental change in the Skagerrak, northeastern North Sea. Sarsia 78:129-139

Muller WA, Lee JJ (1969) Apparent indispensability of bacteria in foraminiferan nutrition. J Protozool 16:471-478

Murray JW (1973) Distribution and ecology of living benthic foraminiferids. Crane, Russak \& Company, New York

Murray JW (1991) Ecology and palaeoecology of benthic foraminifera. Longman Scientific \& Technical, Essex

Murray JW (2001) The niche of benthic foraminifera, critical thresholds and proxies. Mar Micropaleontol 41:1-7

Murray JW, Alve E (2000) Major aspects of foraminiferal variability (standing crop and biomass) on a monthly scale in an intertidal zone. J Foraminifer Res 30:177-191

Murray JW, Bowser SS (2000) Mortality, protoplasm decay rate, and reliability of staining techniques to recognize 'living' foraminifera: a review. J Foraminifer Res 30(1):66-70

Nichols FH, Thompson JK (1985) Time scales of change in the San Francisco Bay benthos. Hydrobiologia 129(1): 121-138

Ohga T, Kitazato H (1997) Seasonal changes in bathyal foraminiferal populations in response to the flux of organic matter (Sagami Bay, Japan). Terra Nova 9:33-37

Powell TM, Cloern JE, Huzzey LM (1989) Spatial and temporal variability in South San Francisco Bay California USA I. Horizontal distributions of salinity suspended sediments and phytoplankton biomass and productivity. Estuar Coast Shelf Sci 28:583-598

Quinterno PJ (1968) Distribution of recent foraminifera in Central and South San Francisco Bay. Master's thesis, San Jose State University, San Jose, CA

Qvale G, Van Weering TCE (1985) Relationship of surface sediments and benthic foraminiferal distribution patterns in the Norwegian Channel, Northern North Sea. Mar Micropaleontol 9:1986

Resig JM, Ming K, Miyake S (1995) Foraminiferal ecology, Ala Wai Canal, Hawai'i. Pac Sci 49:341-366

Rogers CE, McCarty JP (2000) Climate change and ecosystems of the Mid-Atlantic Region. Clim Res 14:235-244

Samir AM (2000) The response of benthic foraminifera and ostracods to various pollution sources: a study from two lagoons in Egypt. J Foraminifer Res 30:83-98

Samir AM, El-Din AB (2001) Benthic foraminiferal assem- 
blages and morphological abnormalities as pollution proxies in two Egyptian bays. Mar Micropaleontol 41:193-227 Schratzberger M, Gee JM, Rees HL, Boyd SE, Wall CM (2000) The structure and taxonomic composition of sublittoral meiofauna assemblages as an indicator of the status of marine environments. J Mar Biol Assoc UK 80:969-980

Seiglie GA (1974) Foraminifers of Mayaguez and Anasco Bays and its surroundings, Part 4. Relationships of foraminifers and pollution in Mayaguez Bay. Caribb J Sci 14: $1-68$

Setty MGAP, Nigam R (1982) Foraminiferal assemblages and organic carbon relationship in benthic marine ecosystem of western Indian Continental Shelf. Indian J Mar Sci 11: 225-232

Setty MGAP, Nigam R (1983) Benthic foraminifera as pollution indices in the marine environment of the west coast of India. Riv Ital Paleontol Stratigr 89:1984

Sherr BF, Sherr EB (1984) Role of heterotrophic protozoa in carbon and energy flow in aquatic ecosystems. In: Klugg IJ, Reddy CA (eds) Current perspectives in microbial ecology. American Society of Microbiology, Washington, DC, p 412-423

Shiba T (1986) Microbial interactions in marine sediments. Mer (Tokyo) 24:97-103

Simpson EH (1949) Measurement of diversity. Nature 163:688

Slater RA (1965) Sedimentary environments in Suisun Bay, California. Master's thesis, University of Southern California, Los Angeles, CA

Thompson JK, Nichols FH (1988) Food availability controls seasonal cycle of growth in Macoma balthica (L.) in San Francisco Bay, California, USA. J Exp Mar Biol Ecol 116(1):43-62
Turley CM, Hughes DJ (1992) Effects of storage on direct estimates of bacterial numbers of preserved seawater samples. Deep-Sea Res Part I Oceanogr Res Pap 39:375-394

Turley CM, Hughes DJ (1994) The effect of storage temperature on the enumeration of epifluorescence-detectable bacterial cells in preserved sea-water samples. J Mar Biol Assoc UK 74:259-262

Upton AC, Nedwell BD, Parkes RJ, Harvey SM (1993) Seasonal benthic microbial activity in the southern North Sea; oxygen uptake and sulphate reduction. Mar Ecol Prog Ser 101(3):273-281

USGS (United States Geographical Survey) (2003) San Francisco Bay water quality data. USGS, Menlo Park, CA. http://sfbay.wr.usgs.gov/access/wqdata/ index.html

Van Duyl FC, Kop AJ (1990) Seasonal patterns of bacterial production and biomass in intertidal sediments of the western Dutch Wadden Sea, Netherlands. Mar Ecol Prog Ser 59:249-262

Velji MI, Albright LJ (1986) Microscopic enumeration of attached marine bacteria of seawater marine sediment fecal matter and kelp blade samples following pyrophosphate and ultrasound treatments. Can J Microbiol 32: $121-126$

Velji MI, Albright LJ (1993) Improved sample preparation for enumeration of aggregated aquatic substrate bacteria. In: Kemp PF, Sherr BF, Sherr EB, Cole JJ (eds) Handbook of methods in aquatic microbial ecology. Lewis Publishers, Chelsea, MI, p 139-142

Yanko V, Ahmad M, Kaminski M (1998) Morphological deformities of benthic foraminiferal tests in response to pollution by heavy metals: implications for pollution monitoring. J Foraminifer Res 28:177-200

Appendix 1. Alphabetic list of genera and species found in this study. Generic assignments follow Loeblich \& Tappan (1987)

Ammonia beccarii (Linné) = Nautilus beccarii Linné, 1758.

Bolivina striatula Cushman, 1922.

Bolivina vaughani Natland, 1938.

Buliminella elegantissima (d'Orbigny) = Bulimina eleganitssima d'Orbigny, 1839 .

Elphidiella hannai (Cushman and Grant) = Elphidium hannai Cushman and Grant, 1927.

Elphidium excavatum (Terquem) = Polystomella excavata Terquem, 1876.

Elphidium gunteri Cole, 1931.

Elphidium incertum $($ Williamson $)=$ Polytsomella umbiculata var. incerta Williamson, 1858 .

Fursenkoina pontoni $($ Cushman $)=$ Virgulina pontoni Cushman, 1932. Remarks: There is a population of foraminifera in the samples used in this study which has 2 different morphological variations. One, which I here call Fursenkoina pontoni forma a (Fig. 5j), has been called F. pontoni in previous studies in San Francisco Bay, and is similar to the type description of $F$. pontoni. The other form, which I call here F. pontoni forma b (Fig. 5k), has been called Hopkinsina pacifica Cushman in previous San Francisco Bay studies (Arnal et al. 1980). While specimens of $F$. pontoni forma b are very similar to specimens described in other studies as F. pontoni, they differ largely in that there is an apertural phlange (Fig. 5k). Because $H$. pacifica was described as having a true apertural lip on a short neck, and was originally described from New Guinea, I feel that $H$. pacifica is not an accurate nomenclature for these specimens. All the specimens of $F$. pontoni forma a and $F$. pontoni forma b are found stained with Rose Bengal in large numbers together in South San Francisco Bay, and are all the same size, suggesting that this is one population with morphological variation, and not 2 distinct species. All of these specimens differ from the original descriptions of both $F$. pontoni in that the coiling is initially triserial, and then biserial (Fig. 5l), while the genus $F$. was originally described as being biserial throughout. Since F. pontoni was described from the Miocene in Florida, I suspect that the specimens used in this study from the Recent in California are probably not the same species as originally described F. pontoni. However, I have chosen here to use the name F. pontoni to be consistent with other San Francisco Bay workers. Trochammina hadai Uchio, 1962.

Trochammina inflata $($ Montagu) = Nautilus inflatus Montagu, 1808. 